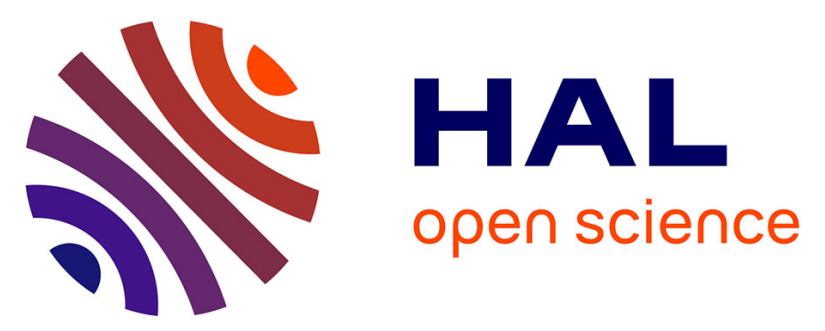

\title{
Demonstration that endoplasmic reticulum-associated degradation of glycoproteins can occur downstream of processing by endomannosidase
}

Nikolay V Kukushkin, Dominic S Alonzi, Raymond A. Dwek, Terry D Butters

\section{To cite this version:}

Nikolay V Kukushkin, Dominic S Alonzi, Raymond A. Dwek, Terry D Butters. Demonstration that endoplasmic reticulum-associated degradation of glycoproteins can occur downstream of processing by endomannosidase. Biochemical Journal, 2011, 438 (1), pp.133-142. 10.1042/BJ20110186 . hal00612965

\section{HAL Id: hal-00612965 https://hal.science/hal-00612965}

Submitted on 2 Aug 2011

HAL is a multi-disciplinary open access archive for the deposit and dissemination of scientific research documents, whether they are published or not. The documents may come from teaching and research institutions in France or abroad, or from public or private research centers.
L'archive ouverte pluridisciplinaire HAL, est destinée au dépôt et à la diffusion de documents scientifiques de niveau recherche, publiés ou non, émanant des établissements d'enseignement et de recherche français ou étrangers, des laboratoires publics ou privés. 


\title{
Demonstration that endoplasmic reticulum-associated degradation of glycoproteins can occur downstream of processing by endomannosidase
}

\author{
Nikolay V. Kukushkin, Dominic S. Alonzi, Raymond A. Dwek, and Terry D. \\ Butters ${ }^{1}$ \\ ${ }^{1}$ To whom correspondence should be addressed (email terry.butters@bioch.ox.ac.uk) \\ Oxford Glycobiology Institute, Department of Biochemistry, University of Oxford, South \\ Parks Road, Oxford OX1 3QU, U.K.
}

Short title: Role for endomannosidase in glycoprotein disposal

Keywords: endoplasmic reticulum-associated degradation (ERAD), endomannosidase, protein quality control, free oligosaccharides, secretory pathway, $\mathrm{N}$-glycosylation

\begin{abstract}
Abbreviations used: 2-AA, 2-anthranilic acid; ConA, Concanavalin A; DTT, dithiothreitol; ECL, enhanced chemiluminescence; EDEM, endoplasmic reticulum degradation-enhancing $\alpha$-mannosidase-like protein; ENGase, endo- $\beta-N$ acetylglucosaminidase; ER, endoplasmic reticulum, ERAD, endoplasmic reticulumassociated degradation; ERGIC, endoplasmic reticulum/Golgi intermediate compartment; FOS, free oligosaccharides; Glc (G), glucose; GlcNAc (N), N-acetylglucosamine; GU, glucose unit; HRP, horseradish peroxidase; MALDI-TOF, Matrix-assisted laser desorption/ionization-time of flight; Man (M), mannose; MANEA, mannosidase, endoalpha; NAP-DNJ, N-(6'-(4"-azido-2"-nitrophenylamino)hexyl)-1-deoxynojirimycin; NBDNJ, N-butyldeoxynojirimycin; PDI, protein disulphide isomerase; PEI, polyethylenimine; PNGase, peptide: N-glycanase; SW, swainsonine; UPR, unfolded protein response.
\end{abstract}

\section{Synopsis}

During quality control in the endoplasmic reticulum (ER), nascent glycoproteins are deglucosylated by ER glucosidases I and II. In the post-ER compartments, glycoprotein endo- $\alpha$-mannosidase provides an alternative route for deglucosylation. Previous evidence suggests that endomannosidase non-selectively deglucosylates glycoproteins escaping quality control in the endoplasmic reticulum, facilitating secretion of aberrantly folded as well as normal glycoproteins. Here, we employ free oligosaccharides (FOS) released from degrading glycoproteins as biomarkers of ERAD, allowing us to gain a global rather than single protein-centered view on ER-associated degradation. Glucosidase inhibition was used to discriminate between glucosidase- and endomannosidase-mediated ERAD pathways. Endomannosidase expression was manipulated in $\mathrm{CHO}-\mathrm{K} 1$ cells, naturally lacking a functional version of the enzyme, and 293T cells. Endomannosidase was shown to decrease the levels of total FOS, suggesting decreased rates of ERAD. However, following pharmacological inhibition of ER glucosidases I and II, endomannosidase expression resulted in a partial switch between glucosylated FOS, released from ERconfined glycoproteins, to deglucosylated FOS, released from endomannosidaseprocessed glycoproteins transported from the ERGIC/Golgi to the ER. Using this 
approach, we have identified a previously unknown pathway of glycoprotein flow, undetectable by the commonly employed methods, in which secretory cargo is targeted back to the endoplasmic reticulum after being processed by endomannosidase.

\section{Introduction}

ER-associated degradation (ERAD) is an essential cellular mechanism for disposal of aberrant and terminally misfolded proteins produced in the lumen of the ER. ERAD is tightly linked to quality control, which for N-glycosylated proteins, comprising the bulk of the secretory pathway cargo, involves glycan trimming and recognition (for review, see [1]). Although substantial progress has been made in studying glycoprotein ERAD targeting in the past decade, the process is far from being fully understood. The classic view on ERAD attributes major roles in glycoprotein disposal solely to ER-localised enzymes and lectins, including ER mannosidase I [2-5], EDEM1-3 [6-8], OS9 [8-10], XTP3-B [10-13] and others.

Recent evidence suggests the involvement of post-ER compartments in the quality control of glycoprotein and ER-associated degradation. Elevation of Golgi mannosidase activity can increase the rates of degradation of mutated glycoproteins [14]. VIP36, a lectin binding high-mannose glycans, was found to recycle between Golgi and ER together with its glycoprotein cargo, suggesting a role for the lectin in ER quality control [15]. A similar role has been proposed for Bap31, a cargo receptor present in both ER and post-ER compartments [16]. Retrograde Golgi-to-ER transport of ERAD substrates has been demonstrated in several other studies in mammalian cells [17-19] and in yeast [20]. Amongst others, endomannosidase was proposed to have a role in ERAD [21,22].

Glycoprotein endo- $\alpha$-mannosidase (MANEA, EC 3.2.1.130) is a Golgi/ERGIC enzyme acting in the early secretory pathway by cleaving an internal $\alpha 1,2$-glucosidic bond between the glucose-substituted mannose residue and rest of the N-linked oligosaccharide. As a result, the glucosyl cap is released from the glycan on the substrate glycoprotein $[23,24]$. This glucosidase-independent deglucosylation allows for evasion of the glycan maturation blockage imposed by glucosidase inhibitors such as castanospermine or N-butyldeoxynojirimycin [25,26]. Following treatment with these inhibitors, endomannosidase has been shown to restore the ability of secreted glycoproteins to acquire fully processed glycans, whereas in cells deficient in endomannosidase activity glucosidase inhibition results in secretion of glucosylated oligomannose glycans [27].

Endomannosidase has been proposed to act in the post-ER quality control system based on (i) the implication that the removal of the terminal mannose residue by endomannosidase would not allow for re-entry of the glycoprotein into the calnexin/calreticulin cycle, mediated by UDP-Glc:glycoprotein glucosyltransferase [28]; (ii) co-localisation of endomannosidase with calreticulin and co-purification of the two proteins on an affinity matrix [29]; and (iii) the mutually exclusive subcellular distribution of endomannosidase and glucosidase II, an enzyme participating in the quality control of proteins in the ER involving the calnexin/calreticulin cycle. However, a more recent finding that under the conditions of glucosidase inhibition, endomannosidase 
non-selectively processes mutated variants of $\alpha 1$-antitrypsin, causing the secretion of the misfolded null-Hong Kong $\alpha 1$-antitrypsin, established that endomannosidase does not discriminate between misfolded and properly folded glycoproteins, therefore denying endomannosidase a role in quality control [30].

Neutral free oligosaccharides (FOS) have been previously identified as biomarkers of ERAD [31]. FOS are generated by a cytosolic peptide:N-glycanase (PNGase) following translocation of degrading glycoproteins from the ER to the cytosol via the sec61 channel [32]. The subsequent catabolism of FOS involves rapid processing by endo- $\beta-\mathrm{N}-$ acetylglucosaminidase (ENGase), cleaving one terminal GlcNAc residue from the

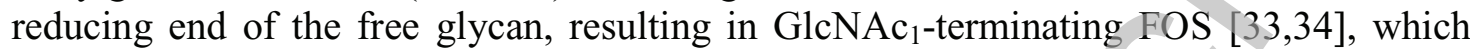
are then further trimmed by cytosolic mannosidases up to a Man ${ }_{5} \mathrm{GlcNAc}_{1}$ structure [35]. The latter is then transported into the lysosome, where the final stages of FOS degradation are mediated by lysosomal mannosidases [36,37]. There is also evidence of an alternative ERAD pathway, in which glycan release and possibly the subsequent degradation of the polypeptide takes place in the lumen of the ER [38-41]. In this case, the resulting GlcNAc $\mathrm{C}_{2}$-terminating FOS are then transported into the cytosol and are processed in the same way as the cytosolically-generated free glycans $[42,43]$.

In physiological conditions, the detectable FOS represent the normal cellular level of ERAD. Free glycans are transiently produced and degraded as described above. However, different populations of FOS can be stabilised by various glycosidase inhibitors. ER glucosidase inhibition results in the inability of glucosylated cytosolic FOS to access the lysosome [44], and also the failure of the ER-generated $\mathrm{GlcNAc}_{2}-$ terminating glucosylated FOS to escape the compartment [43,45]. Cytosolic mannosidases can be inhibited to block the catabolism of FOS following their release in the cytosol. Finally, inhibition of lysosomal mannosidases results in the accumulation of ERAD-derived oligomannose intermediates that fail to progress further in the degradation pathway [46]. FOS analysis has been employed for the evaluation of ERAD in the conditions of glucosidase or mannosidase inhibition, as well as to study ERAD in yeast $[20,31,46]$.

Here, we employ FOS analysis as a method to gain a global view of glycoprotein disposal, and provide evidence that following processing by endomannosidase, a fraction of glycoproteins is further targeted for ER-associated degradation, as opposed to a separate population of substrates that is stabilised by endomannosidase-mediated deglucosylation.

\section{Experimental}

\section{Materials}

Tissue culture media were from Gibco/Invitrogen or Sigma. Cell lines were from ATCC. AnalaR and HPLC grade solvents were from VWR International. Restriction, ligation and PCR enzymes were from NEB UK. Water was Milli-Q grade. pLEXm vector was a gift from Dr. Chris Scanlan (Oxford Glycobiology Institute). Polyethylenimine was from Polysciences, Inc. NB-DNJ was provided by Celltech. YB148 was provided by Dr. Yves Bleriot (Universite de Poitier, France). N-(6'-(4"-azido-2"-nitrophenylamino)hexyl)-1- 
deoxynojirimycin (NAP-DNJ) was provided my M. Lee (Oxford Glycobiology Institute). All other reagents were from Sigma, unless otherwise stated.

\section{Cell Culture}

$\mathrm{CHO}-\mathrm{K} 1$ and $293 \mathrm{~T}$ cells were cultured at $37^{\circ} \mathrm{C}$ in a humidified atmosphere containing $5 \% \mathrm{CO}_{2}$. Cultures were maintained in DMEM supplemented with foetal calf serum (10\%), penicillin $(100 \mu \mathrm{g} / \mathrm{ml})$ and streptomycin $(100 \mathrm{U} / \mathrm{ml})$.

\section{Antibodies}

The following primary antibodies were used: mouse monoclonal to protein disulphide isomerase (PDI), $2 \mu \mathrm{g} / \mathrm{ml}$; mouse monoclonal to giantin, $1 \mu \mathrm{g} / \mathrm{ml}$ (both - Enzo Life Sciences); mouse monoclonal to GM130, $1.25 \mu \mathrm{g} / \mathrm{ml}$, mouse monoclonal to BiP/GRP78, $0.5 \mu \mathrm{g} / \mathrm{ml}$ (both - BD Biosciences); mouse monoclonal to ERGIC53, $10 \mu \mathrm{g} / \mathrm{ml}$ (Santa Cruz Biotechnology); rabbit polyclonal to hemagglutinin (HA tag), $1 \mu \mathrm{g} / \mathrm{ml}$ for immunofluorescence, $0.5 \mu \mathrm{g} / \mathrm{ml}$ for immunoblotting (Sigma); mouse monoclonal to $\beta$ actin, $2 \mu \mathrm{g} / \mathrm{ml}$ (Abcam). The following secondary antibodies were used: goat polyclonal to mouse IgG, horseradish peroxidase (HRP) conjugate, $2 \mu \mathrm{g} / \mathrm{ml}$; goat polyclonal to rabbit IgG, HRP conjugate, $1 \mu \mathrm{g} / \mathrm{ml}$ (both - Abcam), goat polyclonal to mouse IgG, Alexa Fluor 633 conjugate, $4 \mu \mathrm{g} / \mathrm{ml}$; goat polyclonal to rabbit IgG, Alexa Fluor 488 conjugate, $2 \mu \mathrm{g} / \mathrm{ml}$ (both - Invitrogen).

\section{Plasmid Construction}

Full-length human endomannosidase open reading frame (MANEA) was amplified from an IMAGE cDNA clone (Geneservice, UK) using the following primers: (P1) 5'-CATTGAATTCTGTGGAATTGTGAGCGGATA-3';

(P2) 5'-TAGCTCTCGAGTTAAGCGTAATCTGGAACATCGTATGGGTAAGAAACAGGCAGCTGGCGATCT-3'. The resulting hemagglutinin-tagged product was PCR purified, digested with EcoRI and XhoI, and the obtained fragment was ligated into the pLEXm vector following gel purification of both digested vector and insert. Blank plasmid was used as the mock vector.

\section{Transfection of Plasmids}

Conditions were optimised for both cell lines to ensure highest transfection efficiencies. Cells were seeded into 6 -well plates at the densities of $0.3 \times 10^{6}$ cells/well $(\mathrm{CHO}-\mathrm{K} 1)$ or $0.5 \times 10^{6}$ cells $/$ well $(293 \mathrm{~T})$. The following day, plasmids were transfected using polyethylenimine (PEI) for CHO-K1 or Fugene 6 (Roche) for 293T cells. For CHO-K1, media were replaced with $4 \mathrm{ml}$ serum-free DMEM. PEI was mixed with DNA $(3 \mu \mathrm{g}$ DNA per well) at the P:N ratio of $1: 14$ in a $\mathrm{NaCl}$ solution $(150 \mathrm{mM})$ and incubated at room temperature for $10 \mathrm{~min}$. The resulting mix $(400 \mu 1)$ was added dropwise into the wells. Cells were then incubated for $4 \mathrm{~h}$ at $37^{\circ} \mathrm{C}$, after which foetal calf serum was added to the wells up to $10 \%$. Compound treatment was started in fresh medium following an overnight incubation. For transfection of 293T cells with shRNA plasmids, Fugene 6 was mixed with DNA in serum-free medium ( $4 \mu 1$ reagent, $1 \mu \mathrm{g}$ DNA per well, total volume $100 \mu 1$ ), incubated for 45 minutes at room temperature and added dropwise to the cells. 
Treatment was started next day by adding the compound from a concentrated stock solution.

\section{Compound Treatments}

In glucosidase inhibition experiments, cells were treated with either N-butyldeoxynojirimycin (NB-DNJ) at a high concentration $(1 \mathrm{mM})$, or NAP-DNJ at a low concentration $(5 \mu \mathrm{M})$. The latter compound was previously reported to be a more potent inhibitor of both glucosidases I and II than NB-DNJ [47], however in cultured cells at low concentrations it has been noted to cause the accumulation of primarily

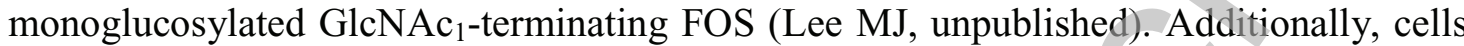
were treated with swainsonine $(\mathrm{SW}, 100 \mu \mathrm{M})$ to inhibit lysosomal FOS processing, YB148 (Compound 1 [46] at $100 \mu \mathrm{M}$ ), an inhibitor of cytosolic mannosidase, to stabilise the cytosolic pool of FOS, and dithiothreitol (DTT, $2 \mathrm{mM}$ ), to induce unfolded protein response (UPR).

\section{Free Oligosaccharide Analysis}

FOS were extracted from cells, labeled with 2-anthranilic acid, and purified by affinity chromatography using Concanavalin A-Sepharose 4B as described previously [31]. Normal-phase high-performance liquid chromatography (NP-HPLC) was used to separate the purified 2-AA labeled FOS according to a previously published method [48]. Glucose unit (GU) values were determined by interpolation from a standard curve obtained by analyzing a 2-AA labeled glucose oligomer standard (partial hydrolysate of dextran).

\section{Western Blotting}

Following SDS-PAGE of crude cell lysates, proteins were transferred to PVDF membranes, which were then blocked in $5 \%(\mathrm{w} / \mathrm{v})$ non-fat dry milk in PBS supplemented with Tween $200.2 \%(\mathrm{v} / \mathrm{v})$ at $4^{\circ} \mathrm{C}$ overnight. Primary and secondary antibodies were diluted in the blocking buffer and incubated with the membrane for $1-2 \mathrm{~h}$, followed by 3 brief washes and $3 \times 5$ min washes in PBS supplemented with $0.05 \%(\mathrm{v} / \mathrm{v})$ Tween 20 . ECL substrate (GE Healthcare) was used for detection in all cases.

\section{Indirect immunofluorescence}

Transfected CHO-K1 cells were grown overnight on coverslips pre-treated with poly-Llysine bromide $(50 \mu \mathrm{g} / \mathrm{ml})$. Cells were washed with PBS, fixed with paraformaldehyde $(2 \%, \mathrm{v} / \mathrm{v})$ for $30 \mathrm{~min}$, blocked in 5\% (w/v) bovine serum albumin in PBS for $30 \mathrm{~min}$, permeabilised with Triton X-100 (1\%, v/v) for $20 \mathrm{~min}$, followed by an incubation with primary antibodies diluted in the blocking buffer, for $1 \mathrm{~h}$. Cells were then washed in PBS supplemented with Tween $20(1 \%, \mathrm{v} / \mathrm{v}), 3 \times 15 \mathrm{~min}$, followed by incubation with secondary antibodies diluted in the blocking buffer, for $1 \mathrm{~h}$. After washing as previously, coverslips were mounted on microscopy slides using Vectashield mounting medium with DAPI (Vector Laboratories). Fluorescent images were obtained using the DeltaVision deconvolution-enhanced wide field fluorescent microscope (Olympus APO 100x/1.4) coupled to a CoolSNAP HQ camera (Photometrics). Deconvolution was carried out using the Applied Precision Resolve 3D algorithm. Images were analysed using ImageJ. 


\section{Endomannosidase assay}

Endomannosidase assay was carried out as described previously [24,27]. Cells were harvested $48 \mathrm{~h}$ post-transfection. Cell pellets were resuspended in NaMES buffer, $0.1 \mathrm{M}$, $\mathrm{pH} 6.5$, containing $0.5 \mathrm{mM}$ DTT and $0.02 \%$ sodium azide. Cells were disrupted using a Branson sonifier $\left(3 \times 10 \mathrm{~s}\right.$ bursts, set. 3). Postnuclear supernatants $\left(600 \mathrm{~g}, 10 \mathrm{~min}, 4^{\circ} \mathrm{C}\right)$ were centrifuged for 20 minutes at $135,200 \mathrm{~g}, 4^{\circ} \mathrm{C}$ to obtain the membrane pellets. After washing with the homogenising buffer, pellets were resuspended in same buffer to a concentration of $15 \mathrm{mg} / \mathrm{ml}$. The assay solutions contained EDTA $(10 \mathrm{mM})$, NB-DNJ (2 $\mathrm{mM})$, deoxymannojirimycin $(2 \mathrm{mM})$ and Triton X-100 $(0.2 \%, \mathrm{v} / \mathrm{v})$. Cell membrane suspensions were preincubated with the inhibitors for $1 \mathrm{~h}$, followed by addition of a 2AA-labeled substrate and subsequent incubation for various time periods. Reaction mixtures were then deproteinated by ultrafiltration using $10-\mathrm{kDa}$ cut-off spin filters (Millipore) and analysed by HPLC as described above.

\section{GlcNAc $_{1} /$ GlcNAc$_{2}$ Analysis of Glucosylated FOS}

GlcNAc$_{1-}$ and $\mathrm{GlcNAc}_{2}$-terminating forms of FOS with longer retention times can coelute on HPLC. Therefore, to accurately determine the ratio between the two groups of glucosylated FOS, a series of enzyme digests was carried out. To isolate glucosylated FOS from deglucosylated species, total 2-AA labelled FOS were first digested with jack bean $\alpha$-mannosidase. Briefly, purified, dried FOS were resuspended in citrate buffer (10 $\mathrm{mM}, \mathrm{pH} 4.5)$ containing zinc acetate $(0.2 \mathrm{mM})$ and $100 \mu \mathrm{U}$ jack bean $\alpha$-mannosidase (Oxford Glycobiology Institute), and incubated at $37^{\circ} \mathrm{C}$ for $24 \mathrm{~h}$. Samples were deproteinated by ultrafiltration as above, and glucosylated FOS were isolated using preparative HPLC. Eluates were dried, and the resulting FOS were digested $37^{\circ} \mathrm{C}$ for 24 $\mathrm{h}$ using recombinant human endomannosidase catalytic fragment generated by expressing a polyhistidine-tagged truncated version of human endomannosidase in E. Coli, followed by inclusion body isolation, Ni-affinity purification of $\mathrm{GuHCl}$-solubilised protein and subsequent refolding, concentration, and buffer exchange to 0.1 M NaMES, pH 6.5 (Kukushkin NV, unpublished). Approx. $0.1 \mu \mathrm{g}$ of purified protein was used per reaction. Following deproteination, reaction products were analysed by HPLC.

\section{Results and discussion \\ Recombinant endomannosidase is functional and localised to the Golgi apparatus}

CHO-K1 cells, naturally lacking functional endomannosidase [49], were transiently transfected with hemagglutinin-tagged human endomannosidase (MANEA). Expression was verified by indirect immunofluorescence and western blotting (Fig 1). Recombinant endomannosidase showed some co-localisation with ERGIC53 (ERGIC marker) and to a greater extent GM130 (cis-Golgi marker), but most significantly with giantin, a more distal (cis- to medial) Golgi marker. No co-localisation with ER marker PDI was detected (Fig 1A). Overall, the observed distribution of recombinant endomannosidase in CHO$\mathrm{K} 1$ cells agreed with the previously reported localisation of the endogenous enzyme in vivo [21]. 
It has been previously reported that endomannosidase is post-translationally modified by phosphorylation, which occurs in the Golgi apparatus [50]. Western blotting of cell lysates following expression of endomannosidase resulted in a double band similar to the one observed previously, suggesting post-translational processing and therefore likely confirming Golgi localisation exhibited by the engineered MANEA construct (assumption without direct experimental proof; Fig. 1, B).

Enzymatic activity of recombinant endomannosidase was confirmed by an enzyme assay. Post-nuclear membrane extracts of $\mathrm{CHO}-\mathrm{K} 1$ cells were incubated with fluorescently labeled oligosaccharide substrates, Glc $\mathrm{Man}_{5} \mathrm{GlcNAc}_{1}$ and $\mathrm{Glc}_{3} \mathrm{Man}_{5} \mathrm{GlcNAc}_{1}$, in the presence of glucosidase and mannosidase inhibitors. Following an overnight reaction, HPLC analysis showed no peak shift caused by mock-transfected CHO-K1 extracts. A complete shift of the substrate peaks to a single peak corresponding to $\mathrm{Man}_{4} \mathrm{GlcNAc}_{1}$, the predicted endomannosidase product, was observed in the case of MANEA-transfected cells (Fig. 1, C).

Finally, the action of recombinant endomannosidase in the glycoprotein-processing pathway was verified by analysing Concanavalin A (Con A) affinity chromatography flow-through following purification of free oligosaccharides extracted from cells treated with NB-DNJ $(1 \mathrm{mM})$. Con A binds most FOS, with only low-molecular weight sugars with no more than one alpha-mannosyl residue generally detected in the flow-through. A peak with $\mathrm{GU}=3.47$ corresponding to $\mathrm{Glc}_{3} \mathrm{Man}_{1}[26]$, a characteristic endomannosidase product in the presence of glucosidase inhibitors, was shown to increase over 5-fold in MANEA-transfected cells (Fig. 1, D). This peak was further confirmed to correspond to a tetrasaccharide by MALDI-TOF (data not shown).

\section{Endomannosidase causes a decrease in total FOS and a relative increase in small FOS concentrations following glucosidase inhibition}

Glucosylated FOS generated in the presence of glucosidase inhibitors are a valuable analysis tool primarily due to their arrested catabolism. In our experiments, however, glucosylated FOS were also employed to discriminate between the conventional ERAD, in which the degradatory pathway is confined to the ER, and a potential route involving shuttling the ERAD substrates between ER and Golgi prior to their degradation. In the former case, processing by glucosidases is the only possible way of removing glucose residues from glycoproteins destined for degradation, resulting in the production of glucosylated FOS following glucosidase inhibition. In contrast to this, the involvement of post-ER compartments would allow for deglucosylation by endomannosidase. In wildtype CHO-K1 cells, however, endomannosidase activity is absent and therefore FOS produced in the presence of glucosidase inhibitors were expected to be predominantly glucosylated whether or not circulation of ERAD substrates between the ER and post-ER compartments takes place. We therefore asked if endomannosidase expression in CHOK1 cells would be reflected in the production of glucosylated/deglucosylated FOS. To address this question, we analysed ConA-binding FOS generated in MANEA-transfected $\mathrm{CHO}-\mathrm{K} 1$ cells in the presence of glucosidase inhibitors. Following a $24 \mathrm{~h}$ treatment with NB-DNJ $(1 \mathrm{mM})$, the major peaks in CHO-K1 FOS HPLC profiles corresponded to triglucosylated oligosaccharides $\mathrm{Glc}_{3} \mathrm{Man}_{5} \mathrm{GlcNAc}_{1}$ and $\mathrm{Glc}_{3} \mathrm{Man}_{7} \mathrm{GlcNAc}_{2}$ (Fig. 2, A, 
and Supplemental Table 1). Endomannosidase expression did not change the ratio between the dominant FOS peaks. However, the total levels of FOS were significantly decreased (Fig. 2, B). This decrease was composed of oligomannosidic glycans with 5 and more mannose residues, but primarily all glucosylated oligosaccharides ("large FOS", Fig. 2, A). At the same time, the relative contribution of FOS with shorter retention times ("small FOS") to the total FOS pool appeared to be increased in endomannosidase-transfected CHO-K1 cells (Fig. 2, C, D). FOS status of untransfected cells, untreated or treated with NB-DNJ, was also assessed and in most cases was not different from mock-transfected cells. A decrease in the levels of $\mathrm{Glc}_{3} \mathrm{Man}_{5} \mathrm{GlcNAc}_{1}$ and a concomitant increase in the levels of $\mathrm{Glc}_{3} \mathrm{Man}_{4} \mathrm{GlcNAc}_{1}$ were significant in mocktransfected CHO-K1 cells, however the differences observed were negligible compared to those between mock- and MANEA-transfected cells (Supplemental Table 2).

\section{Small FOS correspond to putative endomannosidase products}

To determine the origin of the "small FOS" that were relatively increased following endomannosidase transfection in CHO-K1 cells, the corresponding GU values were determined and used to compare with those previously obtained for a range of cellular FOS [31]. To further confirm the structure of the glycans, the eluted "small FOS" were digested with a1,2-mannosidase, and the migration of the peaks was analysed by HPLC. Five peaks were identified as different isomers of GlcNAc 1 -reducing $\mathrm{Man}_{2}-\mathrm{Man}_{4}$ oligosaccharides (Table 1). Of the identified FOS, only a single species bore the D1 mannose residue $\left(\mathrm{Man}_{4} \mathrm{GlcNAc}_{1}\right.$, linear isomer - see Table 1, D1 mannose shown in bold). In sharp contrast to the other identified $\operatorname{Man}_{2}-\mathrm{Man}_{4}$ oligosaccharides, this linear isomer of $\mathrm{Man}_{4} \mathrm{GlcNAc}_{1}$ was not increased in endomannosidase-expressing cells (Table 1). Since the D1 mannose residue is removed by endomannosidase, the selective increase in the production of FOS lacking this residue suggests that they have originated from endomannosidase-processed glycoproteins. It was previously suggested that endomannosidase-mediated deglucosylation acts as a "bypass mechanism" allowing glycoproteins to evade quality control without compromising their end glycosylation. However, our data hereby confirm the existence of an alternative ERAD pathway in which glycoproteins are exposed to post-ER compartments (ERGIC, possibly Golgi) and specifically endomannosidase prior to their degradation.

In contrast to FOS produced in the conventional ER-confined pathway in the conditions of glucosidase blockage, the glycans released from ERAD substrates processed by endomannosidase are deglucosylated and therefore do not accumulate in the cell. They get rapidly processed by cytosolic and then lysosomal enzymes. The detected "small FOS" are therefore transient and their levels could not be quantitatively compared with those of glucosylated FOS generated as a result of the conventional glycoprotein ERAD. Hence, the decrease in total FOS observed in endomannosidase-expressing CHO-K1 cells could be explained by a greater deglucosylated-to-glucosylated FOS ratio and consequently higher susceptibility of the total FOS pool to cytosolic and lysosomal glycosidases. However, endomannosidase-mediated deglucosylation could also prevent some glycoproteins from entering the degradation pathway, resulting in decreased overall FOS release. Such stabilisation of glycoproteins by endomannosidase in the conditions of 
glucosidase inhibition has been previously demonstrated for mutated variants of $\alpha 1$ antitrypsin [30].

To investigate whether both the "FOS-destabilising" and the "glycoprotein-stabilising" mechanisms take place in the cell at the same time, we employed swainsonine, a mannosidase inhibitor primarily used for late-Golgi glycoprotein processing perturbation, but also known to be a potent lysosomal mannosidase inhibitor [46]. Swainsonine therefore arrests the catabolism of FOS at the late stages, predominantly causing the accumulation of the core-type $\mathrm{Man}_{3} \mathrm{GlcNAc}_{1}$ (Fig. 2, A). Following cotreatment of transfected CHO-K1 cells with swainsonine and NB-DNJ, the levels of FOS were decreased in endomannosidase-expressing cells, but to a significantly lesser extent than in cells treated with NB-DNJ alone (approx. $44 \%$ of the decrease seen in the latter case; Fig. 2, B). As expected, the proportion of small FOS was increased in MANEA-expressing cells in both cases (Fig. 2, C, D). Since the catabolism of FOS is blocked in the presence of swainsonine [46], the extent of free oligosaccharide depletion still observed upon swainsonine/NB-DNJ co-treatment was indicative of decreased production rather than increased degradation of FOS, supporting the previous finding that the secretion of glycoproteins is enhanced by endomannosidase in the conditions of glucosidase inhibition [30]. We therefore conclude that both stabilisation of glycoproteins and destabilisation of FOS contribute to the decrease in FOS levels observed in endomannosidase-transfected CHO-K1 cells.

\section{Glucosylated lumenal FOS are not the primary source of small FOS}

Glucosidase inhibition by NB-DNJ in a high concentration results in the accumulation of two types of glucosylated FOS, namely cytosolic and lumenal. The latter fail to get transported across the ER membrane and could potentially become subject to ER/Golgi vesicular trafficking and endomannosidase-mediated deglucosylation [51]. Due to the fast action of ENGase in mammalian cells, cytosolic and lumenal FOS are distinguished by the presence of either one or two GlcNAc residues on the reducing terminus, respectively. To confirm that the "small FOS" upregulated following endomannosidase expression in the conditions of NB-DNJ treatment (see Fig. 2) are not derived from lumenal FOS, we employed NAP-DNJ, a potent NB-DNJ analogue which at low concentrations has been noted to cause the accumulation of primarily monoglucosylated GlcNAc $_{1}$-terminating oligosaccharides, with hardly any GlcNAc$c_{2}$-terminating FOS produced (Fig. 3). To verify this observation, we evaluated the ratio between GlcNAc $_{1}$ and GlcNAc 2 -terminating glucosylated oligosaccharides in NB-DNJ- $(1 \mathrm{mM})$ and NAPDNJ- $(5 \mu \mathrm{M})$ treated cells. For this purpose, glucosylated FOS were separated from deglucosylated species, and following digestion with recombinant endomannosidase, the levels of the resulting $\mathrm{Man}_{3-4} \mathrm{GlcNAc}_{1-2}$ were compared. These final products are clearly distinguishable by HPLC, facilitating discrimination between $\mathrm{GlNNAc}_{1}$ and $\mathrm{GlcNAc}_{2}-$ terminating FOS (Fig. 3, B). In cells treated with $5 \mu \mathrm{M}$ NAP-DNJ GlcNAc -terminating $_{1}$ glycans comprised approx. $90 \%$ of total glucosylated FOS, compared to approx. $55 \%$ in cells treated with $1 \mathrm{mM}$ NB-DNJ. These data confirm the observation that treatment of CHO-K1 cells with NAP-DNJ at a low concentration results in the accumulation of glucosylated FOS that are almost exclusively cytosolic. At the same time, endomannosidase expression together with the treatment causes an approx. 50\% relative 
increase in non-D1-terminating $\mathrm{Man}_{2}-\mathrm{Man}_{4}$ oligosaccharides (Fig. 3, D, E). We therefore conclude that the primary source of "small FOS" is not glucosylated lumenal FOS but glycoproteins undergoing ERAD through the route involving shuttling between the ER and post-ER compartments.

\section{The effect of endomannosidase on FOS is dependent on substrate glucosylation}

To verify that the processing of glucosylated substrates by endomannosidase is the cause of the changes in the FOS profiles of CHO-K1 cells expressing the enzyme, we substituted the glucosidase inhibitors for either dithiothreitol, a commonly used UPRinducing agent, or YB148, a cytosolic mannosidase inhibitor arresting the catabolism of FOS following their release in the cytosol [46]. The effects of these compounds on free oligosaccharides paralleled those of glucosidase inhibitors, namely induction of unfolded protein response and increasing the rates of ERAD [46], or stabilising the cytosolic pool of FOS, respectively. However, glucosidase-mediated deglucosylation of N-linked glycans was unaffected (see Fig. 4 and Supplemental Fig. 1). Consistent with the proposed mechanism of endomannosidase impact on FOS, the effect of the enzyme on FOS in cells treated with YB148 or DTT was much less pronounced than in the case of glucosidase inhibitors. Endomannosidase expression in YB148-treated CHO-K1 cells caused a subtle but significant decrease in the amounts of total FOS (Fig. 4, A, B). No changes in the relative amounts of $\mathrm{Man}_{2}-\mathrm{Man}_{4}$ oligosaccharides were detected, consistent with the YB148-mediated arrest of FOS catabolism on the early stages (Fig. 4, C, D). The effect of endomannosidase in DTT-treated cells was not significant, although the expected upregulation of BiP/GRP78 was observed, indicating the induction of UPR (Supplemental Fig. 1). Taken together, these findings confirm that the observed effect of endomannosidase expression in $\mathrm{CHO}-\mathrm{K} 1$ cells is a specific response to the upregulation of glucosylated substrates induced by glucosidase inhibitors in our experimental system.

\section{Endomannosidase knockdown in 293 Tells leads to increased FOS production}

To verify our findings of the effect of endomannosidase on FOS production, we performed shRNA-mediated knockdown of the enzyme in 293T cells. Four shRNAencoding vectors (pGFP-V-RS, \#1-\#4, OriGene) were tested for their ability to knock down endomannosidase. Prior to the knockdown experiments, two commercially available antibodies (Sigma Cat. No. HPA011046 and SAB2101423) were tested in western blotting experiments. We were however unable to detect specific bands at the predicted molecular weight for any of the cell lines tested, suggesting that endogenous endomannosidase in the cells used was below the level of immunological detection. The latter forced us to verify efficient knockdown by co-transfecting 293T cells with the shRNA-encoding vectors and the MANEA-HA plasmid, similar to the strategy recently employed for ER mannosidase I [7]. HA-tagged endomannosidase expression was then assayed using western blotting (Fig. 5, A).

Out of the four shRNA constructs tested, \#4 appeared to be most efficient $(>90 \%$ attenuation of MANEA-HA overexpression). Knockdown was verified by an activity assay using a triglucosylated substrate. Breakdown of $\mathrm{Glc}_{3} \mathrm{Man}_{5} \mathrm{GlcNAc}_{2}(1 \mathrm{pmol}$ in 10 $\mu \mathrm{l})$ in cell extracts was slowed down dramatically following transfection with \#4. At the 
linear phase of the reaction, the slope of the kinetic curve was decreased 9.7-fold (Fig. 5, B).

The construct was employed in subsequent experiments alongside with the scrambled control vector. 293T cells transfected with the shRNA-encoding plasmid were treated with NB-DNJ $(1 \mathrm{mM})$, and FOS were analysed as described for CHO-K1 cells. Endomannosidase knockdown resulted in both an absolute increase in total FOS produced, and a relative increase in glucosylated oligosaccharides (Fig. 5, C, D). The latter included $\mathrm{Glc}_{3} \mathrm{Man}_{5} \mathrm{GlcNAc}_{1}$, representing the major product of glucosylated FOS cytosolic processing [31], and $\mathrm{Glc}_{3} \mathrm{Man}_{7-9} \mathrm{GlcNAc}_{1 / 2}$, a group of incompletely demannosylated lumenal and cytosolic oligosaccharides. At the same time, a relative increase was observed in some of the deglucosylated FOS, most strikingly the $\mathrm{Man}_{6} \mathrm{GlcNAc}_{1 / 2}$ isomer A, representing a characteristic product of $\mathrm{Glc}_{3} \mathrm{Man}_{7} \mathrm{GlcNAc}_{1 / 2}$ deglucosylation by endomannosidase, or demannosylation of the equivalent $\mathrm{Man}_{7}$ and $\mathrm{Man}_{8}$ species (generated from $\mathrm{Glc}_{3} \mathrm{Man}_{7} \mathrm{GlcNAc}_{1 / 2}$ or $\mathrm{Glc}_{3} \mathrm{Man}_{7} \mathrm{GlcNAc}_{1 / 2}$ species, respectively). Peak identity was based on the reported GU value for the corresponding oligosaccharide [31], and the structure was confirmed by digesting total 2-AA labeled FOS with recombinant endomannosidase catalytic fragment, resulting in the shift of $\mathrm{Glc}_{3} \mathrm{Man}_{7} \mathrm{GlcNAc}_{1 / 2}$ GU value to that of the peak down-regulated following endomannosidase knockdown (Fig. 5, E).

Although we did not observe statistically significant changes in small FOS corresponding to $\mathrm{Man}_{2-4} \mathrm{GlcNac}_{1}$, the decreased level of $\mathrm{Man}_{6} \mathrm{GlcNAc}_{1 / 2}$ isomer A reflects the reduction in endomannosidase activity in a similar fashion to the increase in the relative $\mathrm{Man}_{2-4}$ FOS levels following recombinant endomannosidase expression in CHO-K1 cells. The less pronounced changes in the levels of free oligosaccharides in $293 \mathrm{~T}$ cells may be due to cell-specific kinetics of cytosolic and lysosomal FOS degradation, which is supported by the fact that $\mathrm{Man}_{7-9}$ FOS are primarily associated with the cytosol and become subject to active cytosol-to-lysosome transport in the $<\operatorname{Man}_{7}$ state [52]. It is therefore likely that $\mathrm{Man}_{6} \mathrm{GlcNAc}_{1 / 2}$ represents the transition point between the two stages of FOS catabolism, resulting in higher levels of the oligosaccharide in the steady state and greater susceptibility to endomannosidase knockdown.

In summary, by employing the method of free oligosaccharide analysis to gain a generalised insight to ER-associated degradation, we have obtained data suggesting that endomannosidase suppresses degradation of a fraction of glycoproteins in the presence of glucosidase inhibitors. This supports the reported evidence on abnormal endomannosidase-mediated secretion in castanospermine-treated cells [30]. However, we additionally demonstrate that a significant population of glycoproteins processed by the enzyme still becomes subject to ERAD (Fig. 6). This finding underlines that on a global level misfolded proteins are able to recycle between the endoplasmic reticulum and postER compartments (ERGIC and possibly Golgi) prior to their degradation. . Although such recycling most likely does not depend on additional quality control checkpoints, the uncertain fate of endomannosidase-processed misfolded glycoproteins does not exclude the possibility that additional sorting mechanisms operate at a post-ER location.

\section{Funding}


This work was funded by the Oxford Glycobiology Institute. N. V. K. was supported by Clarendon Fund and New College (Robert Lyns) graduate scholarships.

\section{References}

1. Lederkremer, G. Z. (2009) Glycoprotein folding, quality control and ER-associated degradation. Curr. Opin. Struct. Biol. 19, 515-523

2. Tokunaga, F., Brostrom, C., Koide, T. and Arvan, P. (2000) Endoplasmic reticulum (ER)-associated degradation of misfolded N-linked glycoproteins is suppressed upon inhibition of ER mannosidase I. J. Biol. Chem. 275, 40757-40764

3. Hosokawa, N., Tremblay, L. O., You, Z., Herscovics, A., Wada, I. and Nagata, K. (2003) Enhancement of endoplasmic reticulum (ER) degradation of misfolded null Hong Kong a1-antitrypsin by human ER mannosidase I. J. Biol. Chem. 278, 26287-26294

4. Movsichoff, F., Castro, O. A. and Parodi, A. J. (2005) Characterization of Schizosaccharomyces pombe ER a-mannosidase: $A$ reevaluation of the role of the enzyme on ER-associated degradation. Mol. Biol. Cell 16, 4714-4724

5. Avezov, E., Frenkel, Z., Ehrlich, M., Herscovics, A. and Lederkremer, G. Z. (2008) Endoplasmic reticulum (ER) mannosidase $\mathrm{I}$ is compartmentalized and required for $\mathrm{N}$ glycan trimming to $\operatorname{man}_{5-6} \mathrm{GlcNAc}_{2}$ in glycoprotein ER-associated degradation. Mol. Biol. Cell 19, 216-225

6. Hosomi, A., Tanabe, K., Hirayama, H., Kim, I., Rao, H. and Suzuki, T. (2010) Identification of an Htm1 (EDEM)-dependent, Mns1-independent ERAD pathway in Saccharomyces cerevisiae. J. Biol. Chem. 285, 24324 -24334

7. Termine, D. J., Moremen, K. W. and Sifers, R. N. (2009) The mammalian UPR boosts glycoprotein ERAD by suppressing the proteolytic downregulation of ER mannosidase I. J. Cell Sci. 122, 976-984

8. Clerc, S., Hirsch, C., Oggier, D. M., Deprez, P., Jakob, C., Sommer, T. and Aebi, M. (2009) Html protein generates the N-glycan signal for glycoprotein degradation in the endoplasmic reticulum. J. Cell Biol. 184, 159-172

9. Quan, E. M., Kamiya, Y., Kamiya, D., Denic, V., Weibezahn, J., Kato, K. and Weissman, J. S. (2008) Defining the Glycan Destruction Signal for Endoplasmic Reticulum-Associated Degradation. Mol. Cell 32, 870-877

10. Christianson, J. C., Shaler, T. A., Tyler, R. E. and Kopito, R. R. (2008) OS-9 and GRP94 deliver mutant a1-antitrypsin to the Hrd1-SEL1L ubiquitin ligase complex for ERAD. Nat. Cell Biol. 10, 272-282 
11. Groisman, B., Shenkman, M., Ron, E. and Lederkremer, G. Z. (2010) Mannose trimming is required for delivery of a glycoprotein from EDEM1 to XTP3-B and to late ER-associated degradation steps. J. Biol. Chem. 286, 1292-1300

12. Yamaguchi, D., Hu, D., Matsumoto, N. and Yamamoto, K. (2010) Human XTP3-B binds to alpha1-antitrypsin variant null(Hong Kong) via the C-terminal MRH domain in a glycan-dependent manner. Glycobiology 20, 348-355

13. Hosokawa, N., Wada, I., Nagasawa, K., Moriyama, T., Okawa, K. and Nagata, K. (2008) Human XTP3-B forms an endoplasmic reticulum quality control scaffold with the HRD1-SEL1L ubiquitin ligase complex and BiP. J. Biol. Chem. 283, 20914-20924

14. Hosokawa, N., You, Z., Tremblay, L. O., Nagata, K. and Herscovics, A. (2007) Stimulation of ERAD of misfolded null Hong Kong alphal-antitrypsin by Golgi alpha1,2-mannosidases. Biochem. Biophys. Res. Commun. 362, 626-632

15. Reiterer, V., Nyfeler, B. and Hauri, H.-P. (2010) Role of the lectin VIP36 in post-ER quality control of human alpha1-antitrypsin. Traffic 11, 1044-1055

16. Ladasky, J. J., Boyle, S., Seth, M., Li, H., Pentcheva, T., Abe, F., Steinberg, S. J. and Edidin, M. (2006) Bap31 enhances the endoplasmic reticulum export and quality control of human class I MHC molecules. J. Immunol. 177, 6172-6181

17. Yamamoto, K., Fujii, R., Toyofuku, Y., Saito, T., Koseki, H., Hsu, V. W. and Aoe, T. (2001) The KDEL receptor mediates a retrieval mechanism that contributes to quality control at the endoplasmic reticulum. EMBO J. 20, 3082-3091

18. Hsu, V. W., Yuan, L. C., Nuchtern, J. G., Lippincott-Schwartz, J., Hammerling, G. J. and Klausner, R. D. (1991) A recycling pathway between the endoplasmic reticulum and the Golgi apparatus for retention of unassembled MHC class I molecules. Nature 352, $441-444$

19. Hammond, C. and Helenius, A. (1994) Quality control in the secretory pathway: retention of a misfolded viral membrane glycoprotein involves cycling between the ER, intermediate compartment, and Golgi apparatus. J. Cell Biol. 126, 41-52

20. Hirayama, H., Seino, J., Kitajima, T., Jigami, Y. and Suzuki, T. (2010) Free oligosaccharides to monitor glycoprotein endoplasmic reticulum-associated degradation in Saccharomyces cerevisiae. J. Biol. Chem. 285, 12390-12404

21. Zuber, C., Spiro, M. J., Guhl, B., Spiro, R. G. and Roth, J. (2000) Golgi apparatus immunolocalization of endomannosidase suggests post-endoplasmic reticulum glucose trimming: Implications for quality control. Mol. Biol. Cell 11, 4227-4240 
22. Roth, J., Ziak, M. and Zuber, C. (2003) The role of glucosidase II and endomannosidase in glucose trimming of asparagine-linked oligosaccharides. Biochimie 85, 287-294

23. Lubas, W. A. and Spiro, R. G. (1988) Evaluation of the role of rat liver golgi endo- $\alpha-$ D-mannosidase in processing N-linked oligosaccharides. J. Biol. Chem. 263, 3990-3998

24. Lubas, W. A. and Spiro, R. G. (1987) Golgi endo-a-D-mannosidase from rat liver, a novel N-linked carbohydrate unit processing enzyme. J. Biol. Chem. 262, 3775-3781

25. Moore, S. E. H. and Spiro, R. G. (1990) Demonstration that Golgi endo- $\alpha-D-$ mannosidase provides a glucosidase-independent pathway for the formation of complex N-linked oligosaccharides of glycoproteins. J. Biol. Chem. 265, 13104-13112

26. Mellor, H. R., Neville, D. C. A., Harvey, D. J., Platt, F. M., Dwek, R. A. and Butters, T. D. (2004) Cellular effects of deoxynojirimycin analogues: Inhibition of N-linked oligosaccharide processing and generation of free glucosylated oligosaccharides. Biochem. J. 381, 867-875

27. Karaivanova, V. K., Luan, P. and Spiro, R. G. (1998) Processing of viral envelope glycoprotein by the endomannosidase pathway: Evaluation of host cell specificity. Glycobiology 8, 725-730

28. Sousa, M. C., Ferrero-Garcia, M. A. and Parodi, A. J. (1992) Recognition of the oligosaccharide and protein moieties of glycoproteins by the UDP-Glc:glycoprotein glucosyltransferase. Biochemistry 31, 97-105

29. Spiro, R. G., Zhu, Q., Bhoyroo, V. and Söling, H. D. (1996) Definition of the lectinlike properties of the molecular chaperone, calreticulin, and demonstration of its copurification with endomannosidase from rat liver Golgi. J. Biol. Chem. 271, 1158811594

30. Torossi, T., Fan, J.-Y., Sauter-Etter, K., Roth, J. and Ziak, M. (2006) Endomannosidase processes oligosaccharides of alphal-antitrypsin and its naturally occurring genetic variants in the Golgi apparatus. Cell. Mol. Life Sci. 63, 1923-1932

31. Alonzi, D. S, Neville, D. C. A., Lachmann, R. H., Dwek, R. A. and Butters, T. D. (2008) Glucosylated free oligosaccharides are biomarkers of endoplasmic- reticulum alpha-glucosidase inhibition. Biochem. J. 409, 571-580

32. Wiertz, E. J., Tortorella, D., Bogyo, M., Yu, J., Mothes, W., Jones, T. R., Rapoport, T. A. and Ploegh, H. L. (1996) Sec61-mediated transfer of a membrane protein from the endoplasmic reticulum to the proteasome for destruction. Nature 384, 432-438

33. Cacan, R., Dengremont, C., Labiau, O., Kmiécik, D., Mir, A. M. and Verbert, A. (1996) Occurrence of a cytosolic neutral chitobiase activity involved in oligomannoside 
degradation: a study with Madin-Darby bovine kidney (MDBK) cells. Biochem. J. 313, 597-602

34. Duvet, S., Labiau, O., Mir, A. M., Kmiécik, D., Krag, S. S., Verbert, A. and Cacan, R. (1998) Cytosolic deglycosylation process of newly synthesized glycoproteins generates oligomannosides possessing one GlcNAc residue at the reducing end. Biochem. J. 335, 389-396

35. Kmiécik, D., Herman, V., Stroop, C. J., Michalski, J. C., Mir, A. M., Labiau, O., Verbert, A. and Cacan, R. (1995) Catabolism of glycan moieties of lipid intermediates leads to a single Man5GlcNAc oligosaccharide isomer: a study with permeabilized CHO cells. Glycobiology 5, 483-494

36. Saint-Pol, A., Codogno, P. and Moore, S. E. (1999) Cytosol-to-lysosome transport of free polymannose-type oligosaccharides. Kinetic and specificity studies using rat liver lysosomes. J. Biol. Chem. 274, 13547-13555

37. Saint-Pol, A., Bauvy, C., Codogno, P. and Moore, S. E. (1997) Transfer of free polymannose-type oligosaccharides from the cytosol to lysosomes in cultured human hepatocellular carcinoma HepG2 cells. J. Cell Biol. 136, 45-59

38. Weng, S. and Spiro, R. G. (1997) Demonstration of a peptide: N-glycosidase in the endoplasmic reticulum of rat liver. Biochem. J. 322, 655-661

39. Loo, T. W. and Clarke, D. M. (1998) Quality control by proteases in the endoplasmic reticulum. Removal of a protease-sensitive site enhances expression of human Pglycoprotein. J. Biol. Chem. 273, 32373-32376

40. Spiro, M. J. and Spiro, R. G. (2001) Release of polymannose oligosaccharides from vesicular stomatitis virus $G$ protein during endoplasmic reticulum-associated degradation. Glycobiology 11, 803-811

41. Fayadat, L., Siffroi-Fernandez, S., Lanet, J. and Franc, J. L. (2000) Degradation of human thyroperoxidase in the endoplasmic reticulum involves two different pathways depending on the folding state of the protein. J. Biol. Chem. 275, 15948-15954

42. Moore, S. E. (1998) Transport of free polymannose-type oligosaccharides from the endoplasmic reticulum into the cytosol is inhibited by mannosides and requires a thapsigargin-sensitive calcium store. Glycobiology 8, 373-381

43. Moore, S. E., Bauvy, C. and Codogno, P. (1995) Endoplasmic reticulum-to-cytosol transport of free polymannose oligosaccharides in permeabilized HepG2 cells. EMBO J. 14, 6034-6042 
44. Moore, S. E. H. and Spiro, R. G. (1994) Intracellular compartmentalization and degradation of free polymannose oligosaccharides released during glycoprotein biosynthesis. J. Biol. Chem. 269, 12715-12721

45. Haga, Y., Totani, K., Ito, Y. and Suzuki, T. (2009) Establishment of a real-time analytical method for free oligosaccharide transport from the ER to the cytosol. Glycobiology 19, 987-994

46. Butters, T. D., Alonzi, D. S., Kukushkin, N. V., Ren, Y. and Blériot, Y. (2009) Novel mannosidase inhibitors probe glycoprotein degradation pathways in cells. Glycoconjugate. J. 26, 1109-1116

47. Rawlings, A. J., Lomas, H., Pilling, A. W., Lee, M. J. R., Alonzi, D. S., Rountree, J. S. S., Jenkinson, S. F., Fleet, G. W. J., Dwek, R. A., Jones, J. H. and Butters, T. D. (2009) Synthesis and biological characterisation of novel N-alkyl-deoxynojirimycin glucosidase inhibitors. ChemBioChem 10, 1101-1105

48. Neville, D. C. A., Coquard, V., Priestman, D. A., Te Vruchte, D. J. M., Sillence, D. J., Dwek, R. A., Platt, F. M. and Butters, T. D. (2004) Analysis of fluorescently labeled glycosphingolipid-derived oligosaccharides following ceramide glycanase digestion and anthranilic acid labeling. Anal. Biochem 331, 275-282

49. Torossi, T., Roth, J. and Ziak, M. (2007) A single tryptophan residue of endomannosidase is crucial for Golgi localization and in vivo activity. Cell. Mol. Life Sci. 64, 1881-1889

50. Torossi, T., Guhl, B., Roth, J, and Ziak, M. (2010) Endomannosidase undergoes phosphorylation in the Golgi apparatus. Glycobiology 20, 55-61

51. Durrant, C. and Moore, S. E. H. (2002) Perturbation of free oligosaccharide trafficking in Endoplasmic Reticulum glucosidase I-deficient and castanosperminetreated cells. Biochem. J. 365, 239-247

52. Chantret, I., Fasseu, M., Zaoui, K., Le Bizec, C., Yayé, H. S., Dupré, T. and Moore, S. E. H. (2010) Identification of roles for peptide: N-glycanase and endo- $\beta-N-$ acetylglucosaminidase (Engase1p) during protein N-glycosylation in human HepG2 cells. PloS One 5, e11734 


\section{Tables and Figures}

Table 1. Characterisation of small FOS in transfected CHO-K1 cells treated with NB-DNJ. Transfected CHO-K1 cells were treated with NB-DNJ (1 mM) for $24 \mathrm{~h}$, followed by FOS extraction, fluorescent labeling and analysis by HPLC (Fig. 2). Peak areas were analysed and compared for mock- and MANEA-transfected cells using two-tailed Student's t-tests. The nomenclature used refers to the structure below.

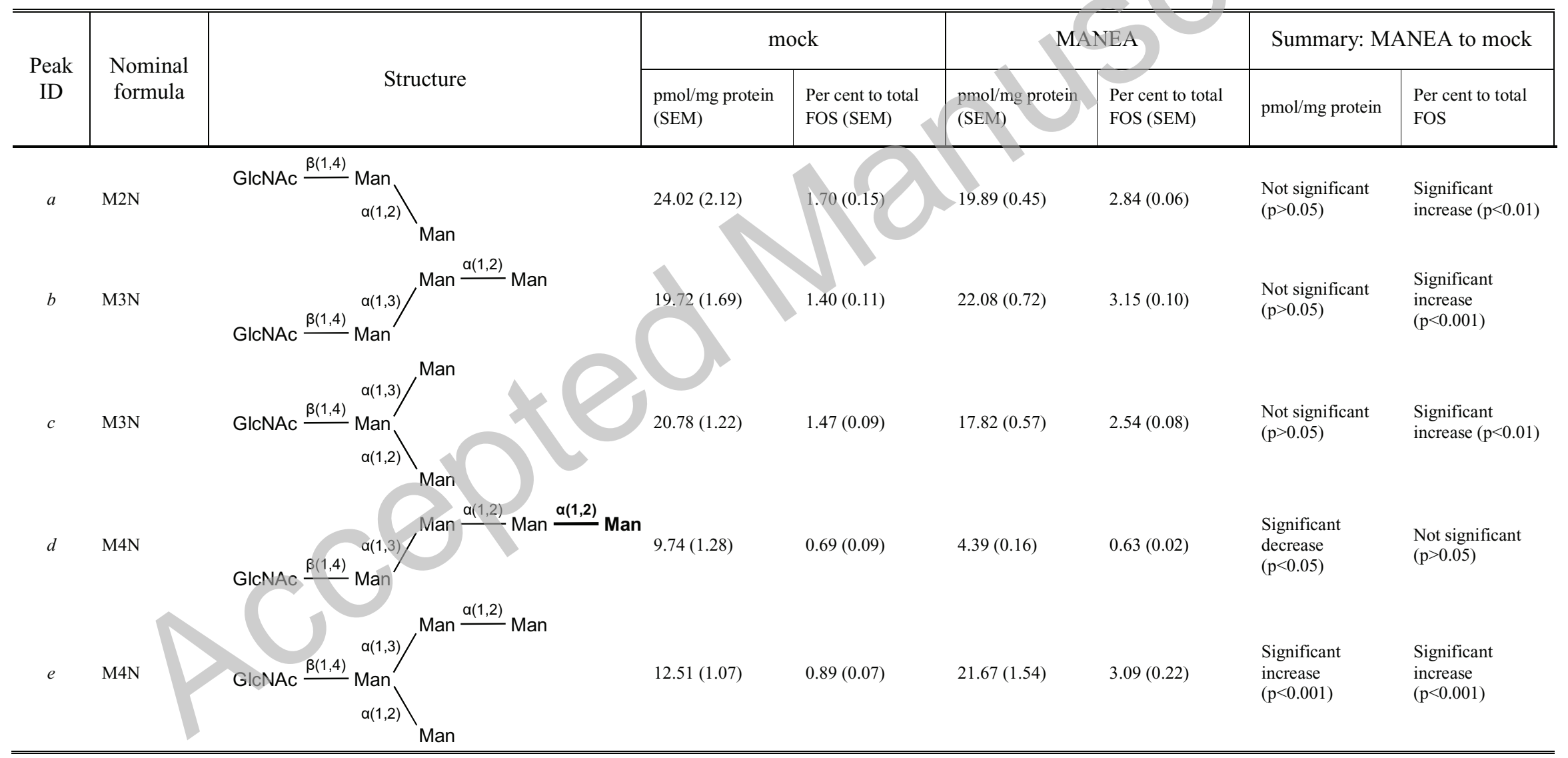


Fig.1. Recombinant endomannosidase is functional in CHO-K1 cells. A, colocalisation of HA-tagged endomannosidase in transfected CHO-K1 cells with ER (PDI), ERGIC (ERGIC53), cis-Golgi (GM130) and cis- to medial Golgi (giantin) markers. Size bars, $5 \mu \mathrm{m}$. B, immunoblot showing expression of endomannosidase in MANEA-transfected cells. Bands are likely to represent unmodified (1) and posttranslationally modified (2) endomannosidase (not verified experimentally). C, endomannosidase activity in transfected cell extracts. 2-AA labeled Glc $\mathrm{Man}_{5} \mathrm{GlcNAc}_{1}$ $(1,3)$ or $\operatorname{Glc}_{3} \operatorname{Man}_{5} \operatorname{GlcNAc}_{1}(2,4)$ were used as substrates in an overnight reaction in the presence of NB-DNJ, DMJ and EDTA. Reaction mixtures were deproteinated and analysed by HPLC. Peak shifts were observed in MANEA-transfected $(3,4)$ but not in mock-transfected $(1,2)$ cell extracts. D, HPLC analysis of 2-AA labeled ConA flowthrough of transfected cell lysates shows an average 5.4-fold increase in $\mathrm{Glc}_{3} \mathrm{Man}_{1}$ levels (data derived from the results of three independent experiments; the result was significant with $\mathrm{p}=0.0034$ )

Fig. 2. Endomannosidase effect on free oligosaccharides in NB-DNJ-treated cells. A, HPLC analysis of FOS extracted from mock- or MANEA-transfected CHO-K1 cells incubated for $24 \mathrm{~h}$ without inhibitors $(\mathrm{u} / \mathrm{t})$, with NB-DNJ or with NB-DNJ and SW. Identified large FOS peaks are numbered and structurally annotated as shown in Supplemental Table 1. Small FOS were further analysed as discussed below. Peaks were labeled and structurally annotated as shown in Table $1 . \mathrm{B}$, total amounts of FOS in the cells, plotted in pmol per $1 \mathrm{mg}$ total protein. C, amounts of small FOS in the cells, plotted on the scale of B. D, proportion of small FOS in the cells, plotted in percent to total FOS. All data shown are representative of three independent experiments, asterisks represent $p$ values in two-tailed unpaired Student's t-tests $\left({ }^{*}, \mathrm{p}<0.05,{ }^{* *}, \mathrm{p}<0.01, * * *, \mathrm{p}<0.001\right)$.

Fig. 3. Independence of endomannosidase effect from glucosylated lumenal FOS. A, HPLC analysis of FOS extracted from mock- or MANEA-transfected CHO-K1 cells incubated for $24 \mathrm{~h}$ with NAP-DNJ $(5 \mu \mathrm{M})$. B, HPLC analysis of 2-AA labeled oligosaccharides obtained by digesting the FOS extracted from NAP-DNJ- or NB-DNJtreated cells with jack bean $\alpha$-mannosidase, followed by isolation of glucosylated FOS and further digestion with recombinant endomannosidase catalytic fragment. Resulting peaks are structurally annotated on the diagram. C, quantitation of total FOS (pmol per 1 mg total protein). D, amounts of small FOS in the cells, plotted on the scale of B. E, proportion of small FOS in the cells, plotted in percent to total FOS. All data shown are representative of three independent experiments.

Fig. 4. Endomannosidase effect on free oligosaccharides in the presence of YB148. A, HPLC analysis of FOS extracted from mock- or MANEA-transfected CHO-K1 cells incubated for $24 \mathrm{~h}$ with YB148. B, quantitation of total FOS (pmol per $1 \mathrm{mg}$ total protein). C, amounts of small FOS in the cells, plotted on the scale of B. D, proportion of small FOS in the cells, plotted in percent to total FOS. All data shown are representative of three independent experiments.

Fig. 5. Effect of endomannosidase knockdown on free oligosaccharide production. A, western blotting analysis of MANEA-HA overexpression in 293T cells upon cotransfection with MANEA/mock plasmids and pGFP-V-RS vectors containing shRNA- 
encoding inserts (\#1-\#4), a scrambled insert (scr) or no insert (empty). B, endomannosidase activity in transfected cell membrane extracts. 2-AA labeled $\mathrm{Glc}_{3} \mathrm{Man}_{5} \mathrm{GlcNAc}_{1}(1 \mathrm{pmol}$ in $10 \mu \mathrm{l})$ was used as a substrate in the presence of NB-DNJ, DMJ and EDTA. Reactions were carried out for various time periods, deproteinated and analysed by HPLC. C, HPLC analysis of 2-AA labeled FOS extracted from 293 T cells transfected with vectors containing the shRNA insert \#4 or the scrambled insert and treated with NB-DNJ $(1 \mathrm{mM})$ for $24 \mathrm{~h}$. D, relative amounts of $\mathrm{Man}_{6} \mathrm{GlcNAc}_{1 / 2}$, Glc $_{3} \mathrm{Man}_{5} \mathrm{GlcNAc}_{1}, \mathrm{Glc}_{3} \mathrm{Man}_{7-9} \mathrm{GlcNAc}_{1 / 2}$ in NB-DNJ-treated $293 \mathrm{~T}$ cells transfected with \#4/scrambled, plotted in percent to total FOS, and total levels of FOS extracted from the cells, plotted in pmol per $1 \mathrm{mg}$ total protein. Data shown are representative of three independent experiments. E, HPLC analysis of 2-AA labeled FOS extracted from 293 T cells treated with NB-DNJ $(1 \mathrm{mM})$ and incubated with either PBS (control) or human endomannosidase catalytic fragment (digest) for $16 \mathrm{~h}$.

Fig. 6. Proposed model for the endomannosidase-mediated ERAD pathway. In physiological conditions (top panel), nascent glycoproteins are deglucosylated predominantly by ER glucosidases I and II (ER Gls) as part of ER quality control (1). Aberrant glycoproteins are subjected to the conventional ER-confined degradation pathway, resulting in the production of deglucosylated FOS (2). Normal glycoproteins proceed further to the post-ER compartments for maturation and secretion (3). A fraction of glucosylated glycoproteins escapes the quality control in the ER and gets transported to ERGIC/Golgi, allowing for deglucosylation by endomannosidase (MANEA) (4). The resulting glycoproteins then enter normal maturation pathways (5). Alternatively, endomannosidase-processed glycoproteins can be recycled back to ER (6) and become subject to ERAD targeting, producing FOS (7). However, in physiological conditions the FOS generated in the latter pathway are indistinguishable from those produced in the conventional ER-confined ERAD. This is opposed to the conditions of glucosidase inhibition (lower panel). In this case, conventional ERAD results in the production of glucosylated FOS that accumulate in the cytosol (8). The endomannosidase-mediated pathway retains a functional deglucosylation step, therefore resulting in deglucosylated FOS (7), eventually subjected to complete degradation via $\mathrm{Man}_{2}-\mathrm{Man}_{4}$ "small FOS" (9). 
A
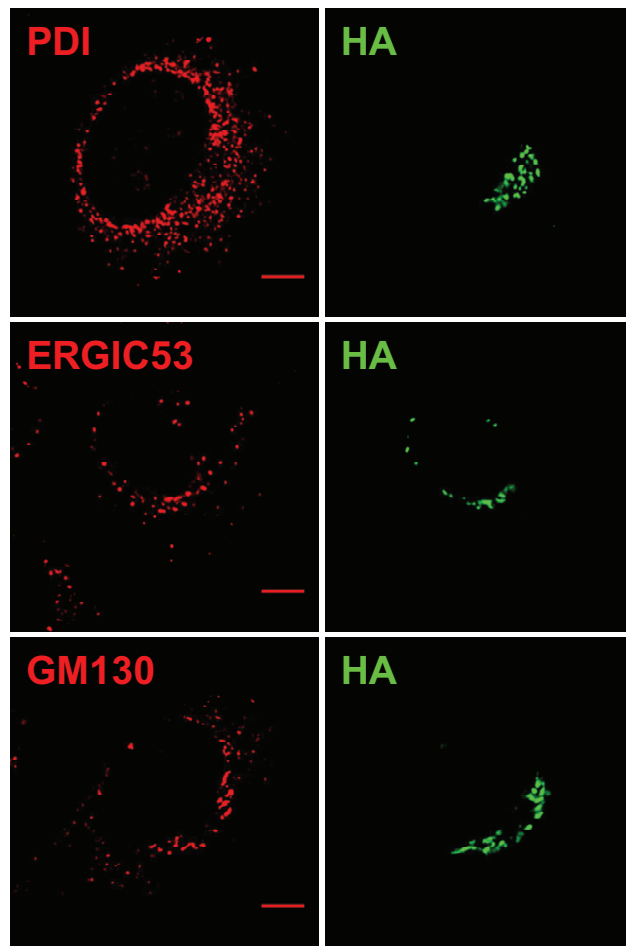

\section{HA}

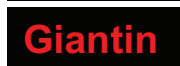

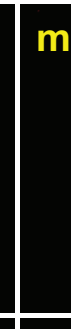
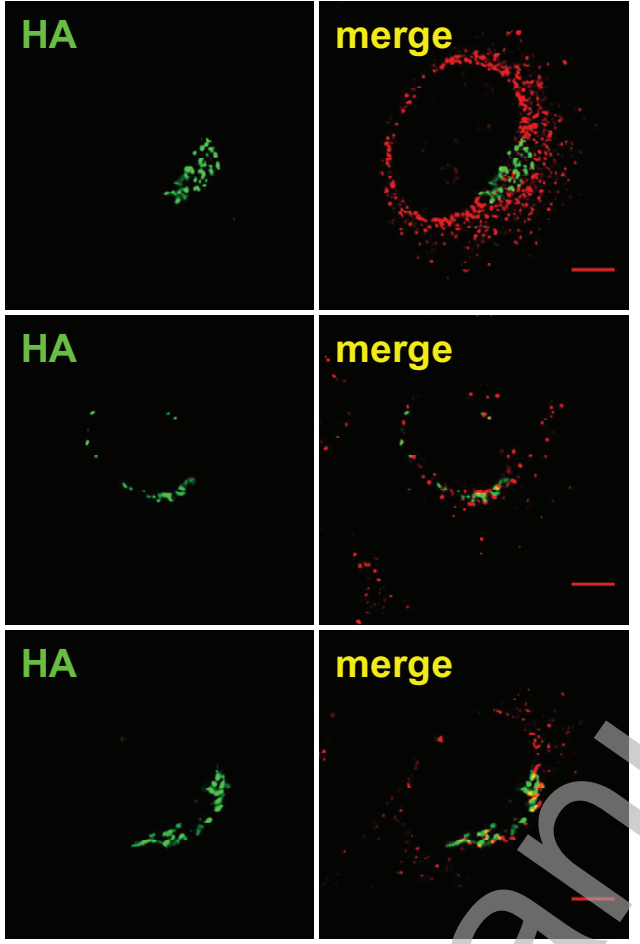

merge
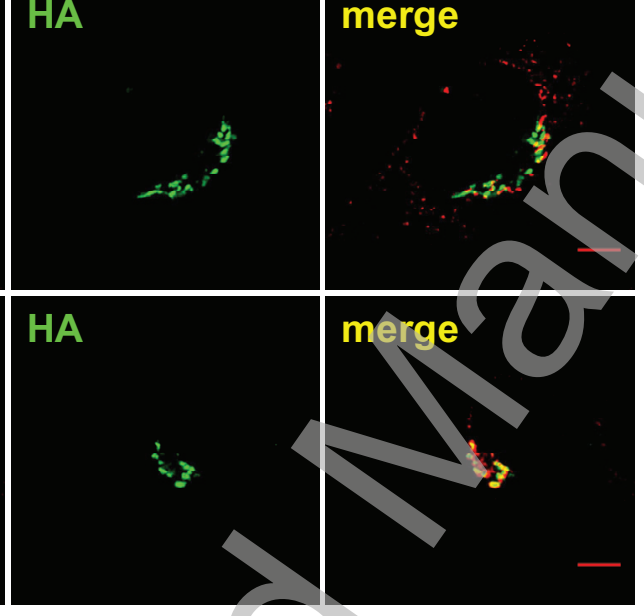

C
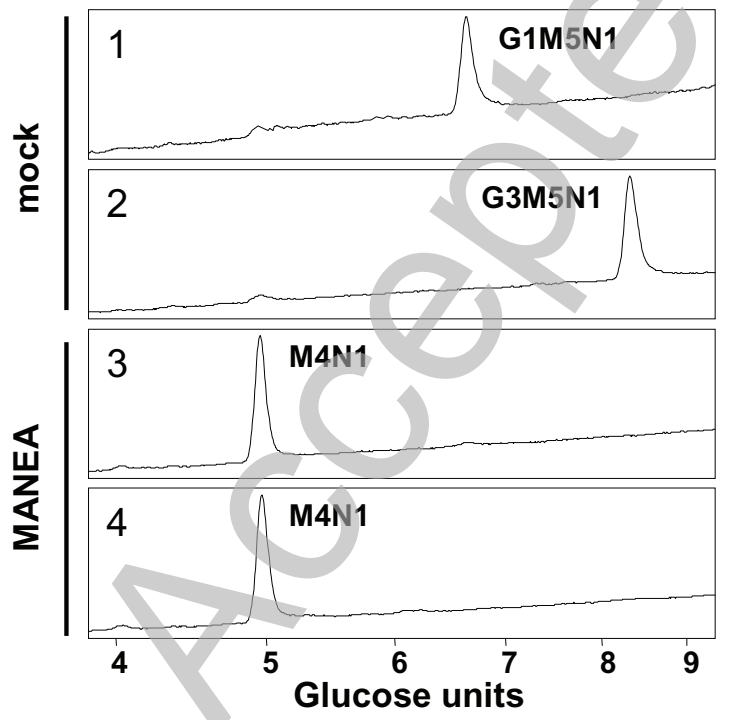

D

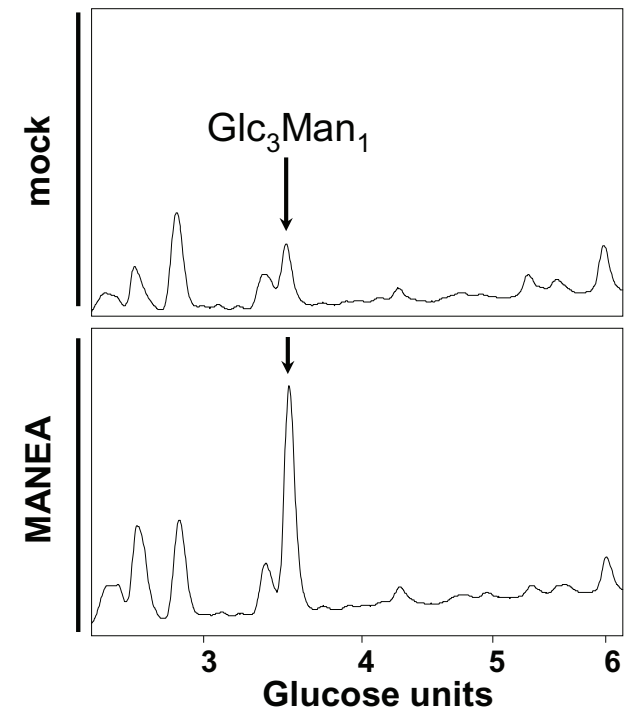



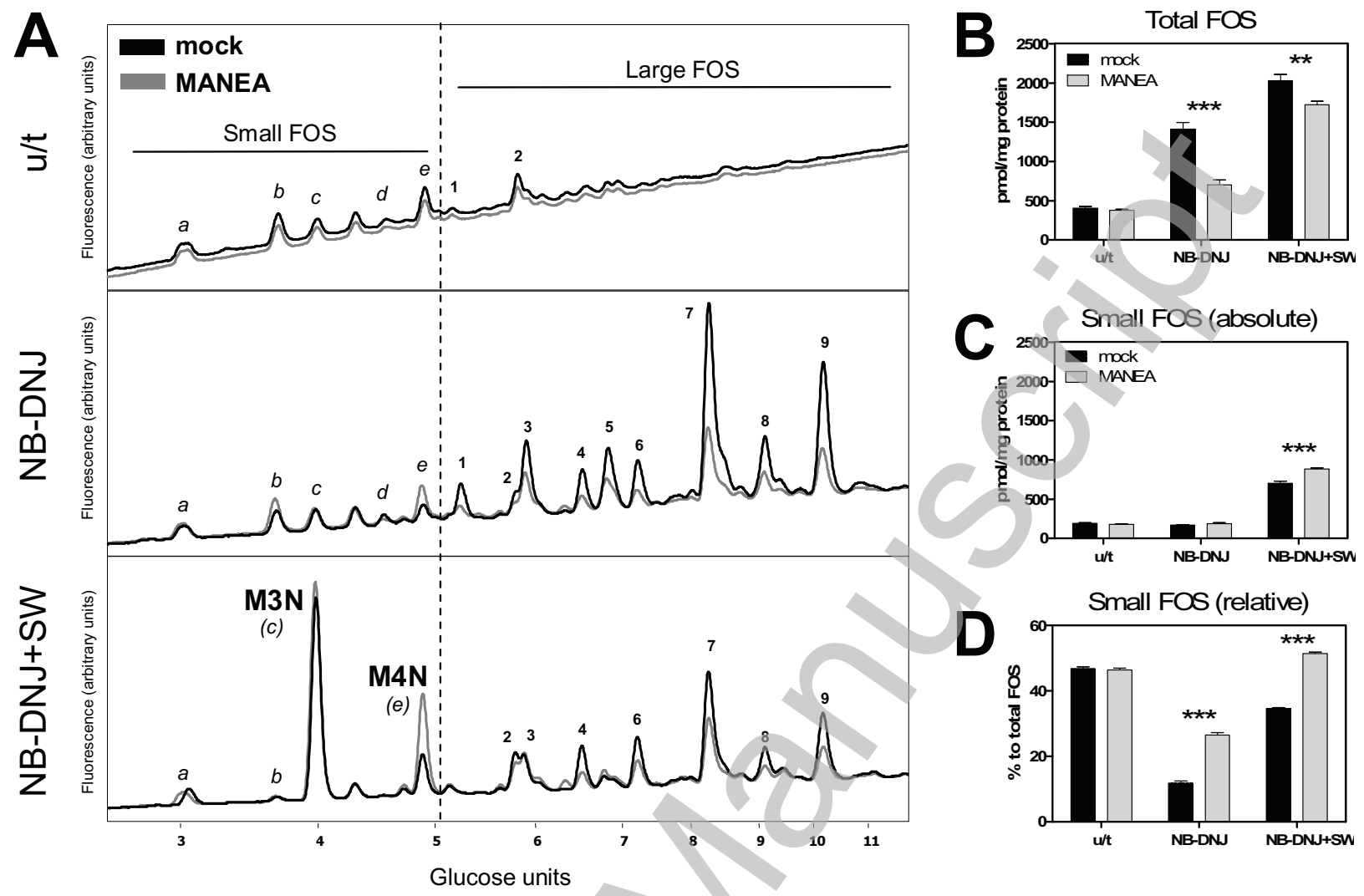



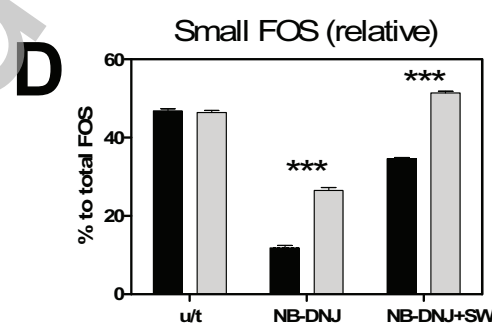

Licenced copy. Copying is not permitted, except with prior permission and as allowed by law. (c) 2011 The Authors Journal compilation (c) 2011 Portland Press Limited 

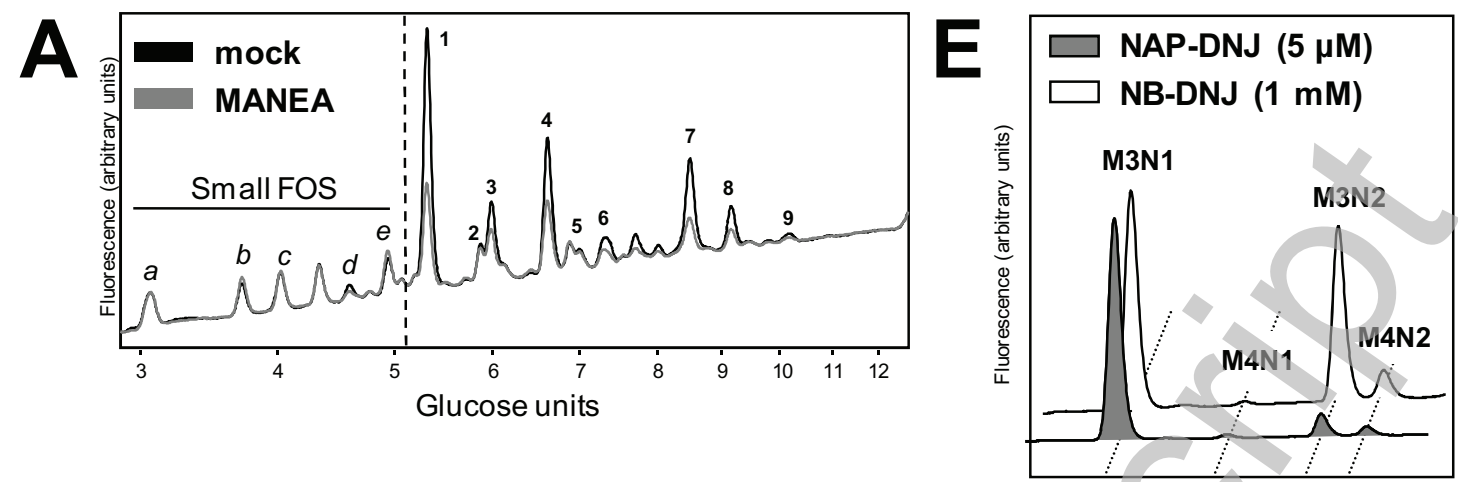

Glucose units
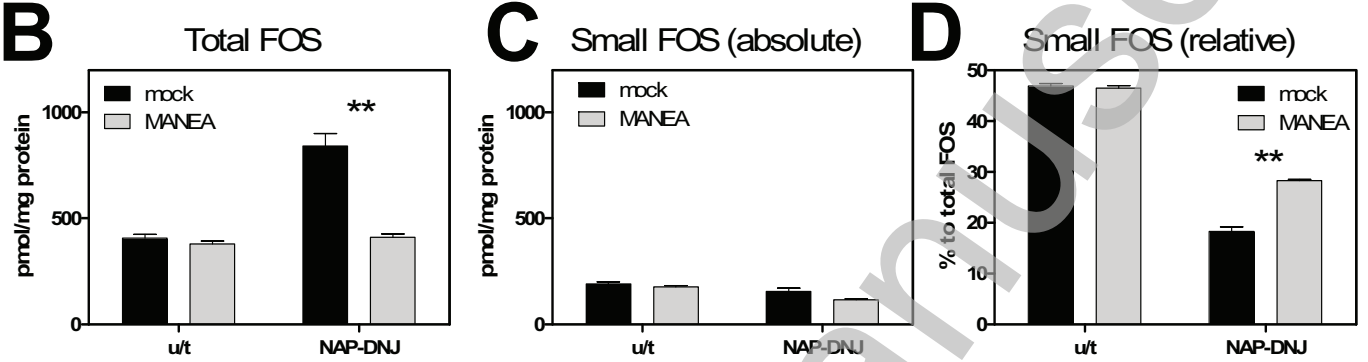


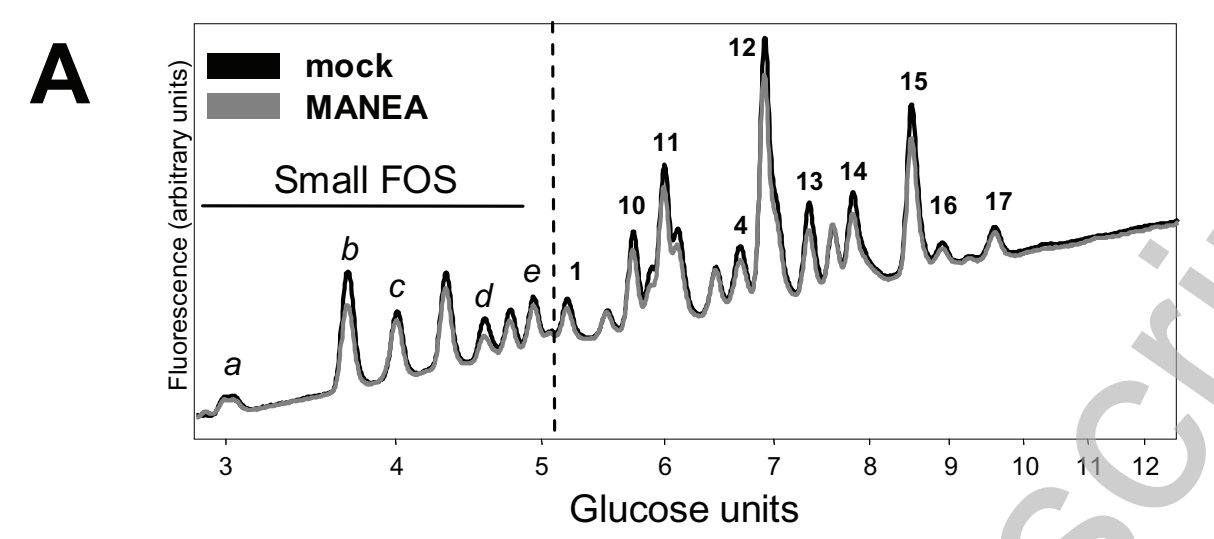

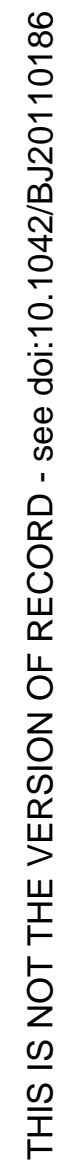

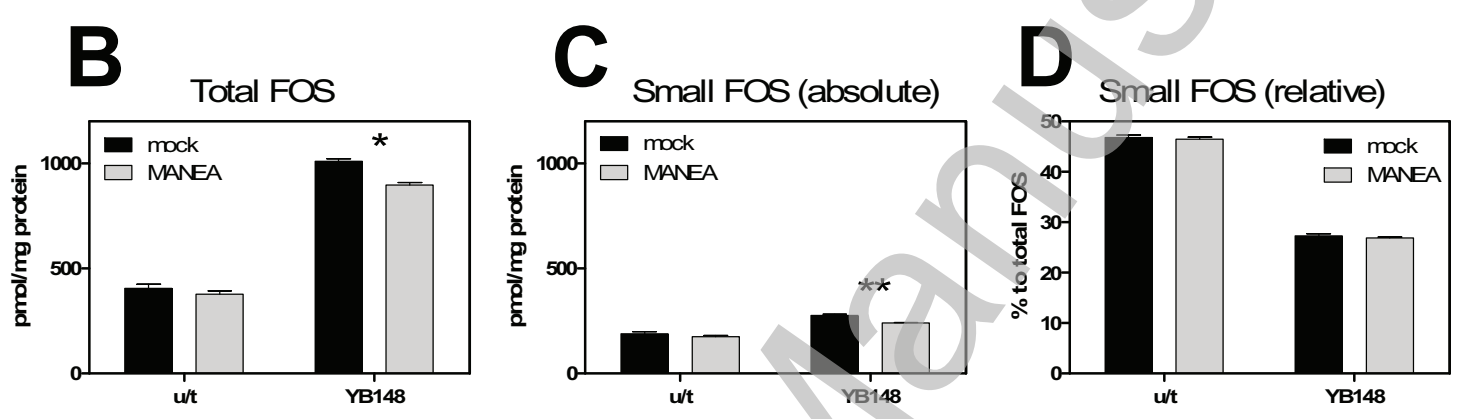


Biochemical Journal Immediate Publication. Published on 18 May 2011 as manuscript BJ20110186

A

B-actin

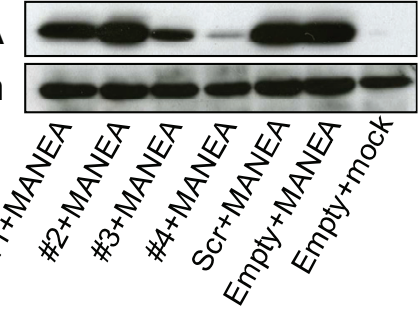

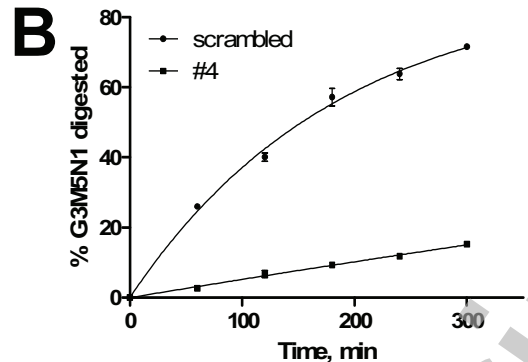

C

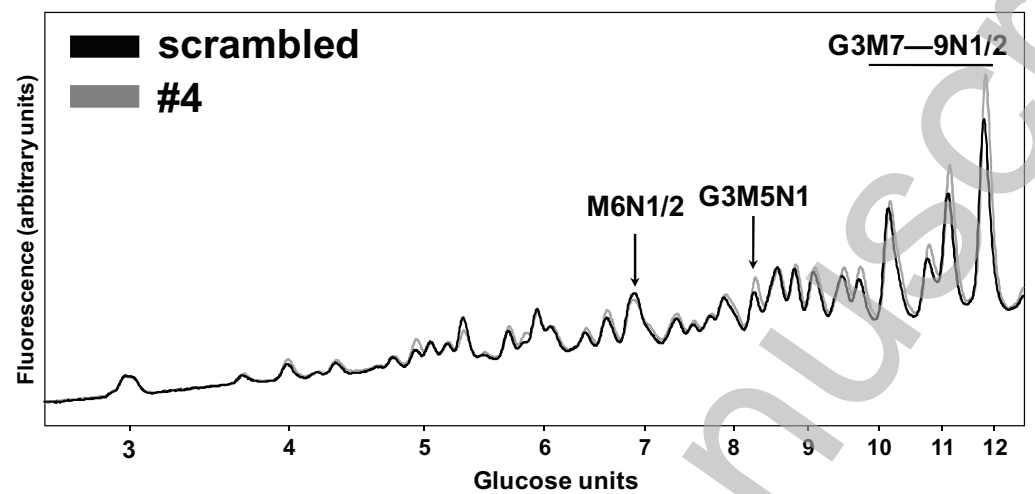

D

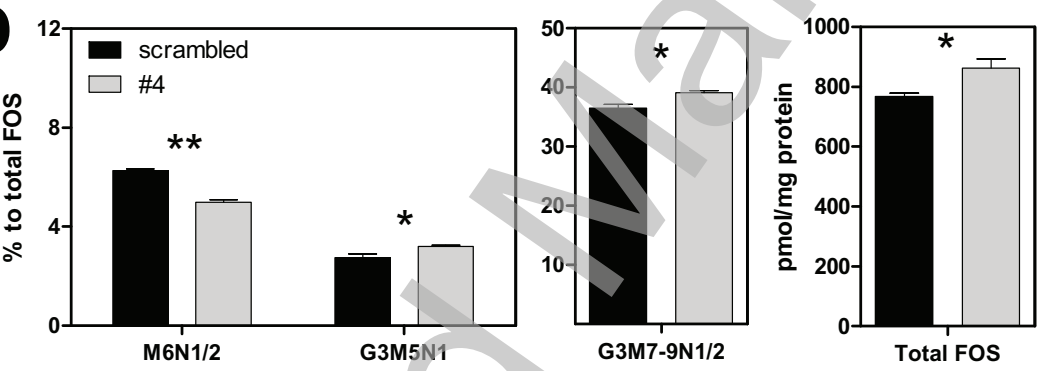

$\mathbf{E}$

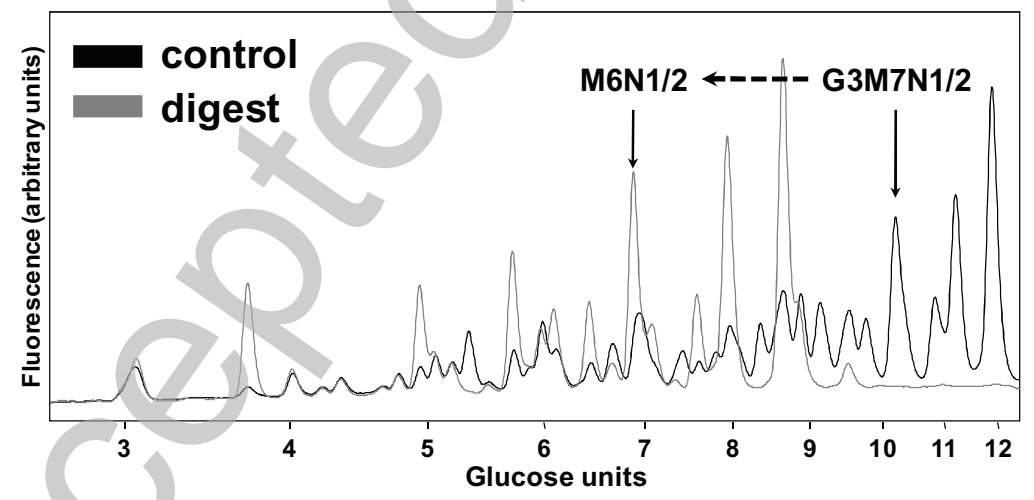

Licenced copy. Copying is not permitted, except with prior permission and as allowed by law. 


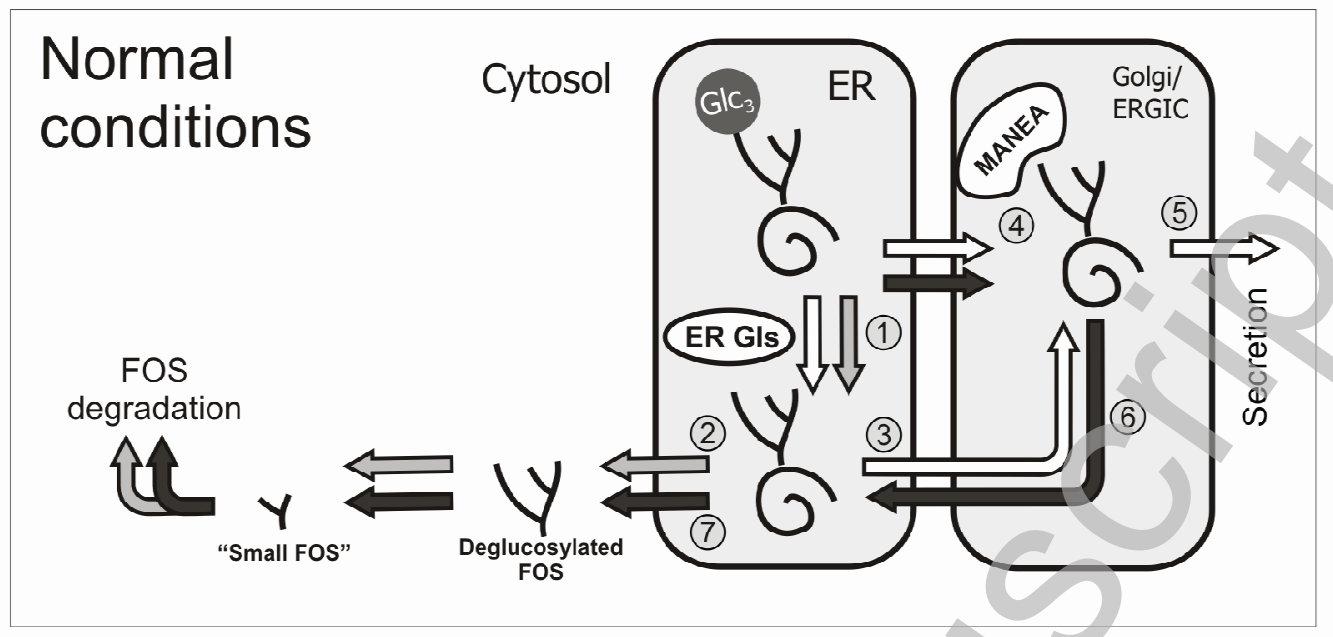

\section{Glucosidase inhibition}

FOS

degradation

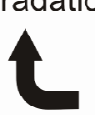

(9)

Cytosol
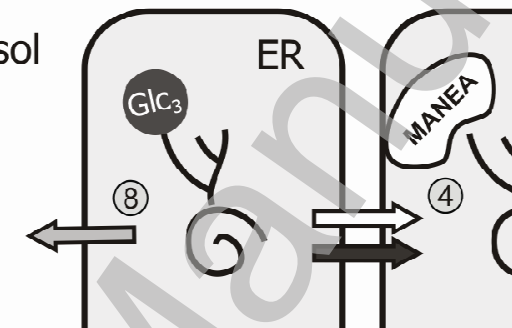
Golgi/ ERGIC

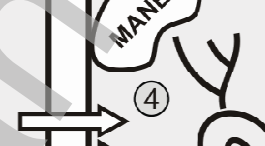

(5)

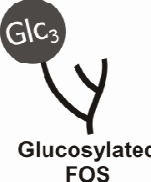

FOS
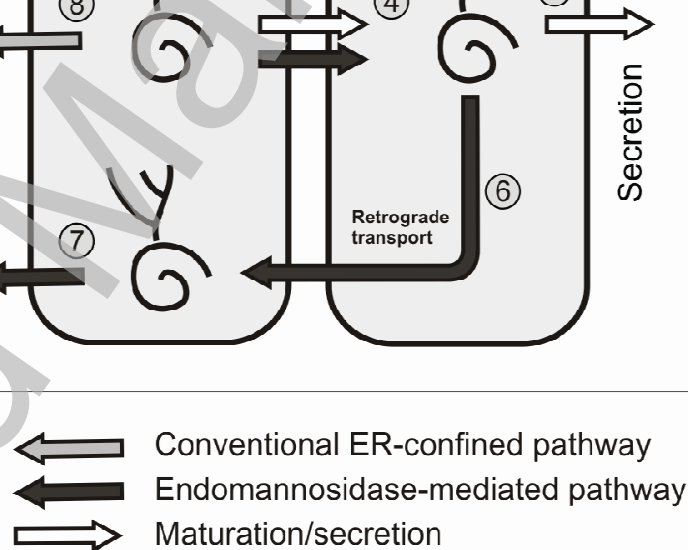